Ročník XVII (2015), číslo 1, s. 126-134/ Volume XVII (2015), Issue 1, pp. 126-134

(c) Mezinárodní politologický ústav / International Institute of Political Science

DOI: $10.5817 / C E P S R .2015 .1 .126$

\title{
Klaus Brummer: Innenpolitik der Außenpolitik: Die Große Koalition, „Governmental Politics“ und Auslandseinsätze der Bundeswehr
}

Wiesbaden: Springer VS. 2013. 307stran. ISBN 978-3-658-01506-0

\section{STANISLAVA ŠERFELOVÁ ${ }^{1}$}

Nasadenie nemeckých ozbrojených síl $\mathrm{v}$ zahraničných misiách predstavuje jednu $\mathrm{z}$ najdiskutovanejš́ch tém $\mathrm{v}$ rámci nemeckej zahraničnej politiky $\mathrm{z}$ viacerých dôvodov. $\mathrm{Na}$ jednej strane si Nemecko uvedomuje dôležitost' svojej zahraničnopolitickej pozície na európskej a medzinárodnej úrovni, v dôsledku čoho klúčoví politickí aktéri deklarujú potrebu zvýšit' úroveň nemeckej angažovanosti pri riešení konfliktov $\mathrm{v}$ rôznych regiónoch sveta, ako aj posilnit' svoje kapacity v oblasti krízového manažmentu. Primárnu úlohu pri rozhodovaní o účasti nemeckých ozbrojených síl na vojenských misiách zohráva pritom princíp efektívneho multilateralizmu, vychádzajúc z predpokladu, že nemecká vojenská angažovanost' sa realizuje výlučne multilaterálne v spolupráci s medzinárodnými organizáciami a nie bilaterálne, resp. unilaterálne. $\mathrm{Na}$ strane druhej je otázka nasadenia ozbrojených síl v zahraničných misiách i pod záštitou medzinárodných organizácií vel’mi špecifická, a to $z$ dôvodu negatívnych skúsenosti z obdobia druhej svetovej vojny, v dôsledku ktorej Nemecko eliminovalo svoj vojenský potenciál a deklarovalo odmietavý postoj $\mathrm{k}$ zbrojeniu a použitiu vojenských prostriedkov pri riešení medzinárodných a regionálnych konfliktov. $V$ uvedenom kontexte dlhodobo presadzovala a v súčasnosti i nad’alej čiastočne presadzuje nemecká zahraničná politika koncept civilnej mocnosti, na základe ktorého ju možno charakterizovat' ako silne hodnotovo založenú politiku, usilujúcu sa o intenzifikáciu multilaterálnej spolupráce, o dodržiavanie medzinárodného práva a odmietajúcu jednostranné použitie sily pri riešení konfliktov. KPúčovú úlohu tak zohrávajú normy a od nich odvodené zahraničnopolitické ciele (Maull 2014) V neposlednom rade je pozornost' pri rozhodovaní o nasadení nemeckých

${ }^{1}$ Interní doktorandka, Katedra mezinárodních vztahů a evropských studií, Fakulta sociálních věd, Masarykova univerzita. Joštova 10, 60200 Brno, Česká republika / Czech Republic. Email: 443407@mail.muni.cz 
ozbrojených síl v zahraničných misiách venovaná i názorom verejnej mienky², ktorej odmietavý postoj $\mathrm{k}$ vojenskej angažovanosti sa Bundeswehru $\mathrm{v}$ značnej miere ovplyvňuje konečné rozhodnutie Spolkového snemu o účasti/neúčasti Nemecka na zahraničných misiách.

$\mathrm{Na}$ základe uvedeného možno konštatovat', že samotný proces rozhodovania o účasti/neúčasti nemeckých ozbrojených síl na medzinárodných misiách podlieha často výraznej rozpoltenosti medzi odmietavými a skeptickými názormi verejnej mienky a medzinárodným tlakom zo strany partnerov, vyžadujúcich viac nemeckej angažovanosti, prevzatie väčšej zodpovednosti za dianie na medzinárodnej scéne, ako aj rozšŕrenie nemeckej soft power zahraničnej politiky o prvky hard power.

Otázkou vplyvu záujmov jednotlivých aktérov nemeckej politiky na rozhodovaní o vyslaní príslušníkov Bundeswehru na zahraničné misie sa zaoberá vo svojej publikácii Innenpolitik der Außenpolitik: Die Große Koalition, „Governmental Politics" und Auslandseinsätže der Bundeswehr Klaus Brummer, pôsobiaci na Inštitúte politických vied Friedrich - Alexander Univerzity v Erlangen-Nürnberg. Autor venuje $\mathrm{v}$ práci pozornost' viacerým aspektom daného rozhodovacieho procesu, a to predovšetkým osobným a organizačným záujmom troch hlavných aktérov spolkovej vlády pri rozhodovaní o vyslaní nemeckých ozbrojených síl do zahraničia; spolkovej kancelárky, ministra zahraničných vecí a ministra obrany; ktorí svojím rozhodnutím a predloženým vládnym návrhom následne usmerňujú i definitívne rozhodnutie poslancov Spolkového snemu o odmietnutí alebo schválení zahraničného nasadenia ${ }^{3}$. Z celkového počtu zahraničných misií, na ktorých sa nemecké ozbrojené sily podiel'ajú, sa Brummer zameral na skupinu tzv.

\footnotetext{
2 Vychádzajúc z výsledkov prieskumu, realizovaného nezávislou Nadáciou Kurta Körbera v spolupráci s Ministerstvom zahraničných vecí Nemecka ako podkladového materiálu pre komplexnú analýzu súčasnej nemeckej zahraničnej politiky Review 2014, prevláda vo verejnosti odmietavý názor voči výraznejšej medzinárodnej angažovanosti sa Spolkovej republiky a predovšetkým voči výraznejšiemu nasadeniu nemeckých ozbrojených síl. $60 \%$ opýtaných zastáva názor, že nemecké zahraničnopolitické vystupovanie by malo byt' i nad'alej zdržanlivé, a to z dôvodov vlastných problémov, negatívnych historických dôvodov, ako aj z dôvodu príliš nízkeho vplyvu vo svete. Zástancovia väčšej angažovanosti vyjadrujú naopak presvedčenie, že Nemecko vd’ačí medzinárodnému obchodu za svoj hospodársky rast a progres, a preto je zaviazané prispievat' k zaisteniu mieru a bezpečnosti vo svete. Zároveň je podl'a nich vnímané zo strany svojich partnerov ako dôležitý sprostredkovatel vo viacerých konfliktoch a krízových situáciách a napokon narastajúci politický a hospodársky význam ho predurčuje k prevzatiu väčšej zodpovednosti vo svete. (Körber Stiftung 2014)

3 Rozhodnutie o vyslaní ozbrojených síl na zahraničné misie prijíma $\mathrm{v}$ konečnom dôsledku Spolkový snem, ktorý rozhoduje o predloženom návrhu spolkovej vlády k vyslaniu/nevyslaniu. Spolková vláda disponuje prednostným právom rozhodovat' nielen o účasti na misii, ale taktiež i o parametroch nasadenia, najvyššom povolenom počte vyslaných vojakov, úlohách vyslaných jednotiek v rámci misie, o oblasti, nákladoch a trvaní celkového nasadenia.
} 
„Petersberských operáciíc4 ${ }^{\text {, }}$ medzinárodných operácií pre krízový a konfliktný manažment realizovaných pod záštitou NATO, EÚ a OSN, konkrétne na nové medzinárodné misie, o ktorých rozhodovala počas svojho funkčného obdobia druhá „vel'ká koalícia“ strán CDU/CSU a SPD v rokoch 2005-2007 pod vedením kancelárky Angely Merkelovej, ministra zahraničných vecí Franka-Waltera Steinmeiera a ministra obrany Franza Josefa Junga. Ide o EÚ misie EUFOR RD Kongo ${ }^{5}$, EUFOR Čad/RCA ${ }^{6}$ a Atalanta ${ }^{7}$.

4 Petersberské rozhodnutia predstavujú skupinu zahranično- a bezpečnostno-politických rozhodnutí, v rámci ktorých aktéri rozhodujú o účasti národných ozbrojených síl na misiách s ciel’om realizácie Petersberských úloh. Tie boli dohodnuté začiatkom 90. rokov na stretnutí Západoeurópskej únie ako súbor humanitárnych úloh, záchranných operácií, úloh pre udržanie mieru, nasadení pri prekonaní kríz vrátane opatrení pre tvorbu mieru. Špecifický charakter týchto operácií sa prejavuje po prvé tým, že ich nemožno priradit' $\mathrm{k}$ žiadnej zvyčajnej kategórii zahranično- a bezpečnostno-politických rozhodnutí. Po druhé sa na rozdiel od rutinných plánovacích rozhodnutí vyznačujú vysokou pravdepodobnost'ou použitia sily a vysokou mnohoznačnost'ou najmä s ohl’adom na vývoj $\mathrm{v}$ oblasti nasadenia. Napokon ich realizácia nepodlieha $\mathrm{v}$ porovnaní s krízovými rozhodnutiami vel'kému časovému tlaku, ani bezprostrednému presadzovaniu národných záujmov zúčastnených štátov.

5 EUFOR RD Kongo predstavuje prvú misiu pod vedením EÚ, o ktorej rozhodovala vel'ká koalícia v rokoch 2005-2009, a zároveň je druhým najväčším nasadením pozemných síl Bundeswehru v Afrike po misii OSN UNOSOM II v Somálsku, realizovanej v rokoch 1993/1994. Spolkový snem schválil rozhodnutie spolkovej vlády o vyslaní pozemných síl do DR Kongo v roku 2006, pričom došlo k vyslaniu približne 780 vojakov a zároveň i k pripravenosti operačnej hlavnej základne a nemeckých operačných velitel'ov. Jednotliví vládni aktéri sledovali odlišné možnosti konania a zapojenia sa do misie, ktoré napokon vyústili do prijatia rozhodnutia o obmedzenom spoluvedení misie spoločne s Francúzskom. Kancelárka presadzovala od začiatku možnost' spolu vedenia operácie s Francúzskom, kým obaja ministri presadzovali opciu vojenskej podpory, pričom sa dosiahlo napokon nezamýšlané kompromisné riešenie. Nemecko tak viedlo na jednej strane hlavnú operačnú základňu, avšak jeho vedúca úloha bola výrazne obmedzená, najmä s ohl'adom na oblast' nasadenia nemeckých síl a celkové trvanie nasadenia.

${ }^{6} \mathrm{~V}$ prípade oboch misií (jak EÚ misie EUFOR, ako aj OSN misii MINURCAT) odmietli nemeckí vládni aktéri vojenskú účast' nemeckých ozbrojených síl pri riešení konfliktu v Čade a Stredoafrickej republike, v ktorých bol vzniknutý konflikt ovplyvnený konfliktom v susednom Sudáne. Napriek odmietavému stanovisku všetkých troch aktérov k vojenskej účasti na daných misiách, sa aktéri zhodli na možnosti politickej podpory misie, a to vyslaním nemeckých vojenských velitel’ov do hlavnej operačnej základne vo Francúzsku. Jednoznačné objasnenie dôvodov pre odmietavé stanovisko všetkých troch aktérov nie je z dôvodu absentujúceho zdrojového materiálu možné.

7 Posledným rozhodnutím vel'kej koalície o nasadení ozbrojených síl, ktoré prijali spolková vláda a Spolkový snem v decembri 2008, bola misia Atalanta. Táto misia predstavuje druhú misiu $\mathrm{s}$ nasadením nemeckého námorníctva v boji proti pirátstvu pri Somálskom polostrove, ktoré malo negatívny dopad tak na núdzou trpiace somálske obyvatel'stvo, ako i na zaistenie bezpečnosti na medzinárodných námorných a obchodných cestách. Negatívny dopad pirátskych aktivít sa prejavil i na nemecké hospodárske a obchodné záujmy, v dôsledku čoho sa všetci traja aktéri rozhodli pre aktívnu účast' nemeckého námorníctva v boji proti pirátstvu, konkrétne vyslaním 1400 vojakov do danej oblasti. Napriek jednotnej pozícii kancelárky aj ministrov k účasti na misii, došlo v priebehu rokovaní o nasadení k presadzovaniu odlišných záujmov medzi ministrami Steinmeierom 
Zároveň sa autor venuje NATO misiám „Allied Provider“, „Allied Protector“ a „Ocean Shield“" ${ }^{\text { } 8}$ a OSN misiám UNIFIL II $^{9}$, UNAMID ${ }^{10}$ a MINURCAT. Ako uvádza Brummer, pri vol'be konkrétnych prípadových štúdií, ako aj konkrétneho obdobia rozhodovania o účasti nemeckých ozbrojených síl na daných operáciách vychádzal z viacerých predpokladov. Oproti predchádzajúcim legislatívnym periódam disponovala vel'ká koalícia Angely Merkelovej silnou väčšinou v Spolkovom sneme, čím sa mohol jednoznačne prejavit' i vplyv zástupcov vlády na rozhodovanie o vyslaní príslušníkov Bundeswehru na multilaterálne misie. Zároveň fokus na nové medzinárodné misie predstavuje príležitost' sledovat', do akej miery sa v prípade rozhodovania o nových nasadeniach výraznejšie prejavia osobné záujmy jednotlivých aktérov rozhodovacieho procesu v porovnaní s predížením účasti Bundeswehru na prebiehajúcich misiách, ked’že rozhodovanie o nových misiách poskytuje spolkovej vláde väčší priestor na jednanie. Spolková vláda musí v týchto prípadoch jasne definovat', či plánuje nasadit' ozbrojené sily $\mathrm{v}$ nových operáciách, za akých podmienok a v akom rozsahu.

Jednotlivé prípadové štúdie tvoria len čast' celkovej publikácie, pričom ich podrobné spracovanie nachádzame v kapitolách 3-7. Každá z uvedených kapitol je prehladne členená na viacero podkapitol, ktoré čitatel’ovi ozrejmujú vývoj situácie $\mathrm{v}$ daných konfliktných regiónoch, ako aj príciny pre zahájenie medzinárodných vojenských misií. Následne sú ilustrované jednotlivé opcie konania aktérov pri rozhodovaní o účasti/neúčasti nemeckých ozbrojených síl $\mathrm{v}$ daných misiách, pričom autor v závislosti od dostupných a relevantných zdrojov

a Jungom. Minister Steinmeier presadzoval zapojenie defenzívnych prostriedkov, zameraných na ochranu civilného obyvatel'stva a odstrašenie pirátov, naproti tomu minister Jung zdôrazňoval nevyhnutnost' zapojenia ofenzívnych prostriedkov, umožňujúcich i priamy zásah prepadnutím proti pirátom. Výsledkom bolo dosiahnutie nezamýšlaného kompromisného riešenia v podobe defenzívno-ofenzívneho vybavenia nemeckého námorníctva pre účely misie.

8 Z dôvodu účasti na misii Atalanta sa nemecké ozbrojené sily na týchto NATO misiách nepodiel'ali.

9 Diskusia o vojenskom zapojení sa do OSN misie UNIFIL II sa začala po eskalácii „Libanonského konfliktu“ medzi Izraelom a Hizbaláhom v júni 2006. Senzibilitu a politickú brilantnost' tejto diskusie možno nachádzat' v špecifickej povahe nemecko-izraelských vzt’ahov, determinovaných vzájomnými negatívnymi historickými skúsenost’ami a pocitom zodpovednosti Nemecka za stabilitu Izraela. Jeho bezpečnost' a zaistenie jeho právnej existencie sa stáva jedným z primárnych raison d'etat Spolkovej republiky Nemecko. V dôsledku uvedeného bolo rozhodnutie o účasti nemeckého námorníctva na OSN misii UNIFIL II prijaté jednotne zo strany každého aktéra a zo strany Spolkového snemu. V dôsledku uvedeného možno konštatovat' dosiahnutie konsenzu, nie kompromisného riešenia. Nemecko vyslalo približne 2400 vojakov a viedlo i jednotku námorného nasadenia.

10 Rozhodnutie k novému nasadeniu Bundeswehru v západosudánskej provincii Darfúr pod vedením OSN spoločne s Africkou úniou bolo prijaté v novembri 2007. Kancelárka a obaja ministri sa zhodli na účasti nemeckých ozbrojených síl na danej misii v nestabilnom sudánskom regióne, ako kontinuitu predchádzajúcej vojenskej angažovanosti Nemecka v misii AMIS (African Union Mission in Sudan), vedenej Africkou úniou. Do misie UNAMID sa zapojilo celkovo 250 nemeckých vojakov. 
vysvetluje dôvody konkrétneho rozhodnutia všetkých troch aktérov so zameraním na ich organizačné a vnútropolitické záujmy. Posledné podkapitoly prípadových štúdií tvorí podrobný popis rozhodovacieho procesu v Spolkovom sneme a postoj nielen vládnych, ale i opozičných parlamentných frakcií.

Prvé dve kapitoly práce sa zameriavajú na teoreticko-metodologické východiska spracovania danej problematiky. V prvej kapitole predstavuje autor pozadie prijatia Petersberských rozhodnutí, objasňuje pozíciu a kompetencie kl'účových nemeckých politických aktérov v rozhodovacom procese o vyslaní ozbrojených síl na zahraničné misie z teoretického, empirického a metodologického hl'adiska. Teoreticky vychádza autor z „Governmental Politics“ modelu (GPM), ktorý je podrobne spracovaný v druhej kapitole práce. Rozhodnutie využit' pri analýze vplyvu záujmov jednotlivých členov vlády na rozhodovanie o účasti/neúčasti nemeckých ozbrojených síl na multilaterálnych misiách pre krízový a konfliktný manažment GPM odôvodňuje autor po prvé tým, že v centre pozornosti GPM stojí práve vplyv jednotlivých vládnych aktérov na zahraničnopolitické rozhodnutia štátu. Pritom sa model opiera o tri základné výpovede, a to tzv. „Stand-Sit“ výpoved” ${ }^{11}$, „Bargaining“ výpoved ${ }^{12}$ a „Resultant“ výpoved" ${ }^{13}$. Druhý dôvod pre využitie GPM spočíva vabsencii analýz rozhodovacích procesov o zahraničnopolitických otázkach $\mathrm{v}$ nemeckom vedeckovýskumnom priestore, vrátane otázky vyslania Bundeswehru na zahraničné misie, ktoré by vychádzali práve z modelu „Governmental Politics“. Z uvedeného dôvodu sa autor rozhodol svojou komplexnou analýzou vyplnit' existujúcu analytickú medzeru a zdôraznit' význam GPM pre skúmanie zahraničnoa bezpečnostno-politického konania vládnych aktérov. Napokon argumentuje autor tým, že GPM umožňuje odhalit' dynamiky a procesy rozhodovania v parlamentných politických systémoch, $\mathrm{v}$ ktorých zastáva predseda vlády silnejšiu pozíciu pri rozhodovaní ako jednotliví ministri. Politický systém Nemecka je vhodným príkladom uvedeného systému na základe prevládajúceho kancelárskeho princípu, upevňujúceho dominantnú pozíciu spolkového kancelára v spolkovej vláde voči ostatným rezortným ministrom. Pri analýze však nedochádza len k jednoduchej aplikácii uvedeného GPM v parlamentnom politickom systéme, ale najmä $\mathrm{k}$ jeho prispôsobeniu a hlbšiemu rozvinutiu prostredníctvom d’alšej teórie

\footnotetext{
11 Stand-Sit výpoved' tematizuje výber možností jednania aktérov na základe organizačných a osobných záujmov.

12 Bargaining výpoved’ zameriava sa na spolupôsobenie aktérov počas vládneho rozhodovacieho procesu, čím sa predpokladá, že žiaden z aktérov nebude rozhodovat' autonómne, ale prejavia sa takzvané delené kompetencie aktérov, avšak každý z aktérov má záujem zvolit' si pre svoje konanie a rozhodovanie najvýhodnejšiu možnost' a presadit' ju voči ostatným.

13 Resultant výpoved' kladie dôraz na konečný výsledok rozhodovania, predpokladajúc zamýšlané alebo nezamýšlané kompromisné riešenie „intendierende/unintendierende Kompromiss-entscheidung“", ked’že žiaden z vládnych aktérov nedisponuje dostatočnou mocou svoje vlastné záujmy a zvolenú možnost' konania presadit' proti odporu ostatných aktérov.
} 
zahraničnej politiky, a to „Poliheuristic Theory of Decision Making“ (PHT) ${ }^{14}$, v konkrétnych prípadových štúdiách.

Aplikovaním GPM vo vyššie uvedených medzinárodných operáciách sleduje Brummer dva primárne ciele. $\mathrm{Na}$ jednej strane ide o hodnotenie platnosti, ako aj výpovednej hodnoty GPM na základe skúmania súvislosti medzi nezávislými premennými- záujmami vládnych aktérov- a závislými premennými- úpravou Petersberských rozhodnutí. $\mathrm{Na}$ strane druhej autor predpokladá, že prípadové štúdie predstavujú vhodný nástroj pre zistenie, aká je skutočná aplikovatel’nost', dosah GPM a podmienky, za ktorých môže GPM d’alej rozvinút', prípadne zúžit' svoju výpovednú hodnotu.

Empirický fokus práce, ako bolo uvedené vyššie, nachádzame v konkrétnych rozhodnutiach spolkovej vlády v období 2005-2009.Zvoleným medzinárodným misiám, EUFOR RD Kongo, EUFOR Čad/RCA, Atalanta, „Allied Provider“, „Allied Protector“, „Ocean Shield“, UNIFIL, UNAMID a MINURCAT, nie je podl'a autora venovaná vo vedeckej literatúre dostatočná pozornost', prípadne len minimálna s ohl’adom na pozadie a priebeh jednotlivých misií, nie však s ohl’adom na rozhodovací proces a osobné či organizačné záujmy vládnych aktérov pri rozhodovaní o nemeckej účasti/neúčasti na daných misiách.

Z metodologického hladiska spája autor komparáciu prípadových štúdií na základe štruktúrovanej a koncentrovanej komparácie („structured focussed comparison") s výskumom jednotlivých prípadov použitím analýzy procesu (,process-tracing“). Štruktúrovaná a koncentrovaná komparácia slúžia ako nástroje pre dosiahnutie čo najvyššej miery porovnatel’nosti medzi výsledkami jednotlivých prípadových štúdií („,cross-case comparisons“), pričom štruktúrovaný charakter tejto metódy sa prejavuje v použití identického súboru otázok vo všetkých prípadoch, umožňujúc tak štandardizáciu údajov a vzájomné porovnanie skúmaných prípadov. Charakter koncentrácie použitej metódy je viditel'ný v zohl'adnení len niektorých špecifických aspektov jednotlivých prípadov. Využitie analýzy procesu $v$ rámci jednotlivých prípadov umožňuje objasnit', či existuje kauzálne prepojenie medzi jednou alebo viacerými nezávislými a závislými premennými s dôrazom na špecifické aspekty daných prípadov.

Vychádzajúc z hodnotenia Klausa Brummera, všetky analyzované prípadové štúdie ilustrujú centrálne charakteristiky Petersberských rozhodnutí ako krízových rozhodnutí o vyslaní ozbrojených síl do zahraničia, ked’že spĺňajú dve podmienky, a to podmienku použitia sily a podmienku mnohoznačnosti nasadenia. V niektorých aspektoch však dané misie nezodpovedajú až tak jednoznačne kritériám krízových rozhodnutí. Krízové rozhodnutia prijímajú vládni aktéri zvyčajne pod výrazným časovým tlakom, avšak s výnimkou misie UNIFIL II nebol na predstavitel’ov spolkovej vlády vyvijaný žiaden výrazný časový tlak.

${ }^{14}$ PHT definuje rozhodovanie ako dvojstupňový proces zahrňujúci kognitívne ako aj racionálne prvky. 
V prípade operácií UNAMID a EUFOR RD Kongo bol vláde poskytnutý dokonca netypicky dlhý časový priestor viacerých mesiacov. Zároveň nepredstavoval vývoj $\mathrm{v}$ žiadnom z konfliktných regiónov bezprostredné nebezpečenstvo pre bezpečnost' a teritoriálnu integritu Nemecka. Napokon v dvoch prípadoch, UNIFIL II a Atalanta, prijímala spolková vláda rozhodnutie o nasadení Bundeswehru v čase, ked' obe z týchto misií už prebiehali. Analyzované misie taktiež odzrkadl'ujú vplyv záujmov troch kl’účových aktérov vlády na rozhodovanie o nemeckej účasti/neúčasti, pričom vo všetkých prípadoch má čitatel' možnost' sledovat' vplyv nielen organizačných záujmov kancelárky, ministra zahraničných vecí a ministra obrany, ale aj ich osobných záujmov, predovšetkým vnútropoliticky motivovaných dôvodov (názor verejnej mienky, postoj vlastnej politickej frakcie). Vol'ba najvhodnejšej možnosti a spôsobu zapojenia nemeckých ozbrojených síl $\mathrm{v}$ daných misiách tak zodpovedá podmienke dosiahnut' čo najväčšie zisky a úžitok a čo najmenšie náklady z účasti na misii.

Z uvedeného vyplýva, že „Stand-Sit“ výpoved” GPM modelu predstavuje vhodný nástroj pre objasnenie vol’by konania zo strany všetkých troch vládnych aktérov. V niektorých prípadoch dochádza $\mathrm{k}$ jasnej odchýlke od očakávaného spôsobu konania týchto aktérov, to znamená, že napriek očakávanému kompromisnému rozhodnutiu pre rozličné možnosti zapojenia nemeckých ozbrojených síl do jednotlivých skúmaných operácií prijali všetci traja aktéri identické rozhodnutia. Napriek odlišným postojom k možnostiam konania $\mathrm{v}$ konkrétnych misiách $\mathrm{v}$ prvej fáze rozhodovania, zameranej na organizačné záujmy aktérov, viedla dominancia osobných záujmov v druhej fáze rozhodovania k prijatiu rovnakej možnosti konania zo strany všetkých troch predstavitel'ov vlády. Rozhodovacie procesy o misiách UNIFIL II, UNAMID, EUFOR Čad/RCA a MINURCAT tak prispeli kidentickej vol'be konania, k hladkému priebehu rozhodovacieho procesu a v konečnom dôsledku ku konsenzuálnemu rozhodnutiu. Naproti tomu pri rozhodovaní o účasti na misiách EUFOR RD Kongo, Atalanta došlo k napätiu pri vol'be vhodného spôsobu konania zo strany spolkovej kancelárky a oboch ministrov. Je zrejmé, že pri rozhodovaní o účasti/neúčasti nemeckých ozbrojených síl na uvedených misiách zohráva klúčovú úlohu viacero faktorov, ako napríklad vplyv externého prostredia, tlak zo strany partnerov, ciel', oblast', rozsah a charakter nasadenia konkrétnej misie.

Analýza uvedených misií z hl'adiska záujmov vládnych aktérov upozorňuje i na d’alšie možnosti výskumu danej problematiky v budúcnosti. Z teoretického hladiska poukazuje autor na možnosti ešte hĺbkovejšej analýzy jednotlivých prípadov z pohladu aplikovaného GPM modelu, ako i na možnosti využitia d’alších teoretických východísk ako napríklad tzv. „prospect theory“, objasňujúcej, či sa rozhodovanie aktérov nachádza v zóne ziskov alebo strát a aká je miera rizika. Zároveň vzniká priestor aplikovat' tzv. „resource dependency“ teóriu s ciel'om skúmat' konzekvencie nerovného rozdelenia moci medzi aktérmi, alebo tzv. „multiple streams“ v kontexte nezamýšl’aných výsledkov rozhodovacích 
procesov. Metodologicky spočíva najväčšia výzva pre autorov, zaoberajúcich sa danou problematikou, $\mathrm{v}$ prístupe $\mathrm{k}$ relevantným zdrojom a informáciám k tematike bezpečnostnej politiky, čím dochádza ku komplikáciám pri použití GPM, ako aj k istému obmedzeniu výpovednej hodnoty jednotlivých analýz. Pozitívum a prínos práce $z$ metodologického hladiska však spočíva podl’a môjho názoru v rozhodnutí autora posilnit' výpovednú hodnotu dostupných zdrojových materiálov o konkrétne názory a postoje aktérov, vysoko postavených úradníkov ministerstva obrany, zahraničných vecí a Úradu spolkového kancelára a poslancov Spolkového snemu k jednotlivým misiám prostredníctvom priamych rozhovorov. Z posledného empirického hladiska je možné doplnit' predloženú analýzu o skúmanie rozhodovania aktérov o predížení účasti na misii, čo by umožňovalo sledovat', do akej miery sa menil vplyv záujmov jednotlivých aktérov pri rozhodovaní o novej misii a jej následnom predížení. Výrazné zmeny by sa očakávali v prípade misií, pri ktorých došlo k prijatiu nezamýšlaného kompromisného riešenia a ktoré sú svojou povahou špecifické, ako napríklad misie na Balkáne alebo v Afganistane.

Predložená publikácia Klausa Brummera je z môjho pohl’adu prínosnou publikáciou voblasti výskumu nasadenia nemeckých ozbrojených síl na zahraničných misiách. Najväčší prínos práce vidím v prepojení teórie a praxe, ktoré umožňuje čitatel'ovi bližšie sa oboznámit' s dôvodmi konkrétnych rozhodnutí hlavných aktérov pri rozhodovaní o vyslaní nemeckých ozbrojených síl do zahraničia; spolkovej kancelárky, ministra zahraničných vecí a ministra obrany. Aplikovaním modelu „Governmental politics“ rozšíreného o polyheuristickú teóriu rozhodovania dokázal autor podrobne analyzovat’ organizačné a osobné vnútropolitické dôvody rozhodnutí vládnych aktérov, ktoré boli ovplyvnené sériou d’alších faktorov. Význam práce spočíva i v objektivite skúmanej problematiky, a to zohl’adnením širokého spektra teoretických východísk, metodologických konceptov, dostupných zdrojov a relevantných informácí $\mathrm{k}$ danej téme. Výberom špecifického obdobia a obmedzeného počtu

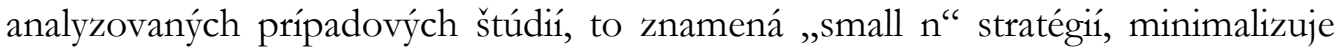
problémy so zovšeobecnením faktov o jednotlivých prípadových štúdiách. Svoje predpoklady ohladom vývoja jednotlivých prípadových štúdií potvrdzuje alebo zamieta kombináciou procesnej analýzy jednotlivých prípadov s komparáciou výsledkov dosiahnutých $\mathrm{v}$ jednotlivých prípadoch, čím dosahuje vysokú mieru porovnatel’nosti a kvality výskumu. Myslím si, že daná publikácia komplexným spracovaním problematiky vypíňa existujúcu medzeru vo výskume dôvodov nasadenia nemeckých ozbrojených síl $\mathrm{v}$ zahraničných misiách z pohladu vplyvu záujmov klúčových aktérov na rozhodovací proces, čím sa stáva vhodným informačným materiálom tak pre vedecko-výskumných pracovníkov, ako aj študentov politických vied a medzinárodných vzt’ahov. 


\section{Bibliografie}

Körber Stiftung. 2014. „Einmischen oder zurückhalten? Ergebnisse einer repräsentativen Umfrage von TNS Infratest Politikforschung zur Sicht der Deutschen auf die Außenpolitik,“ online (http://www.koerber-stiftung.de/internationale-politik/sonderth emen/umfrage-aussenpolitik.html (cit. 10.05.2015)

Maull, Hans. 2014. „Deutschlands außenpolitische Kontinuität ist richtig.“ Review 2014 Außenpolitik Weiter Denken, online (http://www.aussenpolitik-weiter-denken.de/de /aussensicht/show/article/die-aussenpolitische-kontinuitaet-ist-richtig-muss-aberangepasst-werden.html) (cit. 10. 05. 2015) 